\title{
On two spider genera new to Russia (Aranei: Corinnidae, Sparassidae)
}

\section{O двух родах пауков, новых для фауны России (Aranei: Corinnidae, Sparassidae)}

\author{
Yuri M. Marusik \& Grigory V. Kuzminykh \\ Ю.М. Марусик, Г.В. Кузьминых
}

Institute of Biological Problems of the North, RAS, Portovaya Str. 18, Magadan 685000, Russia.
Институт биологических проблем Севера ДВО РАН, ул. Портовая 18, Магадан 685000.

KEY WORDS: Paratrachelas, Heteropoda, disjunctive range, new record, Far East.

КЛЮЧЕВЫЕ СЛОВА: Paratrachelas, Heteropoda, дизъюнктивный ареал, новая находка, Дальний Восток.

ABSTRACT. Two genera and two species are reported from Russia for the first time: Paratrachelas acuminus (Zhu et An, 1988) and Heteropoda venatoria (Linnaeus, 1767). They were found in the Maritime Province. Both species are illustrated.

РЕЗЮМЕ. Два рода и два вида впервые отмечены в России: Paratrachelas acuminus (Zhu et An, 1988) и Heteropoda venatoria (Linnaeus, 1767). Оба вида найдены в Приморье. Приведены рисунки.

\section{Introduction}

During last three decades, the known spider fauna of Siberia and Russian Far East has increased from 500 species to almost 1900 [Marusik, 2007]. Five families (Ctenidae, Cybaeidae, Leptonetidae, Mysmenidae, Oonopidae), over a dozen genera, and many species new to Russia or Russian Far East have recently been found in Maritime Province. Nevertheless fauna of the Asian part of Russia remains poorly studied. The goal of our study is to present data about two genera newly found in Maritime Province.

\section{Material and methods}

Specimens were photographed using an Olympus Camedia E-520 camera attached to an Olympus SZX16 stereomicroscope. The images were montaged using "CombineZM" image stacking software. Photographs were taken in dishes of different size with paraffin in the bottom. Different sized holes were made in the bottom to keep the specimens in the correct position. In terminology of the female copulatory organs, we follow Bayer \& Jäger [2009]. We invented one new term - posterior lobe. All measurements are given in $\mathrm{mm}$.
Museum abbreviations:

IBPN - Institute for Biological Problems of the North, Magadan, Russia.

ZMMU - Zoological Museum of Moscow State University, Moscow, Russia.

\section{Taxonomic survey \\ Family CORINNIDAE Karsch, 1880}

Corinnidae is fairly large globally distributed family with almost 1000 species [Platnick, 2010]. This family was represented in Russia by two genera (Phrurolithus C.L. Koch, 1839, and Trachelas L. Koch, 1866) with about a dozen species [Mikhailov, 1997].

\section{Paratrachelas Kovblyuk \& Nadolny, 2009}

Type species Trachelas maculatus Thorell, 1875.

COMMENTS. Paratrachelas was recently described [Kovblyuk \& Nadolny, 2009] for two species, Trachelas maculatus and T. acuminus (Zhu et An, 1988). The genus has a Palaearctic disjunctive range. The former species is known from Hungary and Bulgaria to Crimea [Kovblyuk \& Nadolny, 2009], and the latter species was known from eastern China and Korea [Platnick, 2010]. While both species were known in countries adjacent to Russia (Ukraine: Crimea and Korea) the genus was not known in Russia.

It is worth mentioning that this genus has a rather unusual range. There are several genera that have a disjunction between Caucasus and Far East: (Myrmarachne MacLeay, 1839; Phintella Strand, 1906; Yaginumena Yoshida, 2002; Howaia Lehtinen \& Saaristo, 1980 [Marusik et al., 2005]; Mysmenella Brignoli, 1980; Meta C.L. Koch, 1836, and several others), but all of 


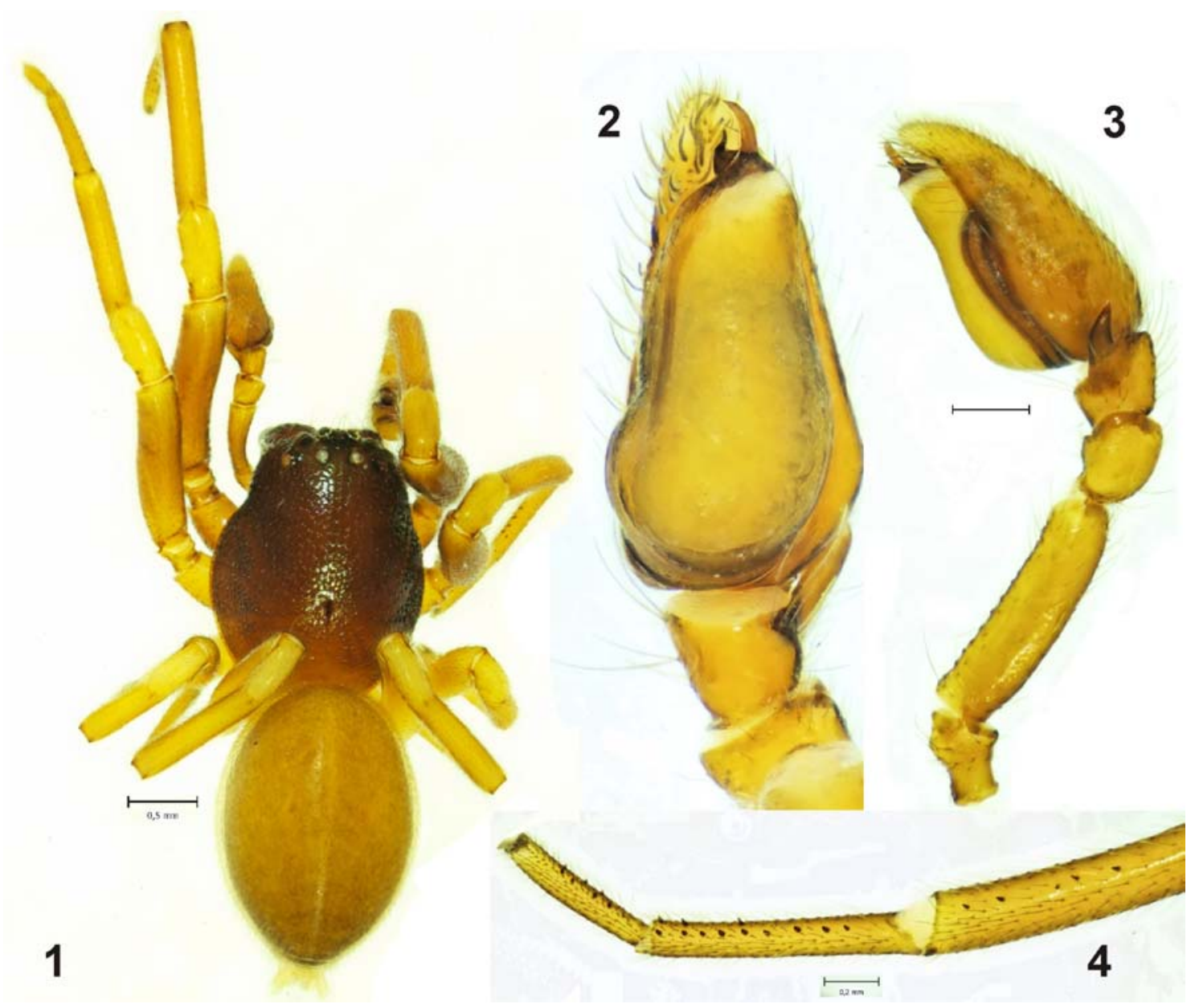

Figs 1-4. Male of Paratrachelas acuminus: 1 - body, dorsal; 2 - palp, ventral; 3 - whole palp, retrolateral; 4 - leg I ventral showing cusps.

Рис. 1-4. Самец Paratrachelas acuminus: 1 - габитус, сверху; 2 - пальпа, снизу; 3 - вся пальпа, ретролатерально; 4 - нога I снизу, показаны шипики.

these genera are known in more southern areas south of the Palaearctic. We do not know of any other genera with this type of range.

DIAGNOSIS. Members of this genus can be easily distinguished from these of Trachelas by the lack of patellar apophysis, having retrolateral tibial apophysis and distinct anterior pocket of epigyne. In addition males of Paratrachelas have no dorsal abdominal scutum.

Paratrachelas acuminus (Zhu \& An, 1988) Figs 1-5.

Clubiona acumina Zhu \& An, 1988: 72, f. 1-6 (O'o). Trachelas coreanus Paik, 1991: 200, f. 1-11 (D + ). Trachelas acumina: Song et al., 1999: 429, f. 255O-P, 256E$\mathrm{F}\left(\bigcirc^{\top}+\right)$.

Trachelas coreanus: Namkung, 2003: 452, f. 35.3a (+).

Trachelas a.: Zhang et al., 2009: 43, f. 1-10 ( $\left.\sigma^{7}+\right)$.

For the whole list of taxonomic references, see Platnick [2010].

MATERIAL EXAMINED. RUSSIA: $1 \sigma^{7} 1$ juv. (IBPN), [17]

Maritime Prov. S part Lazovski Res. Korpad' Camp, $43^{\circ} 16^{\prime} \mathrm{N}$
134을 E, 6-9.08.1998 (Yu.M. Marusik); $10^{7}$ (ZMMU), [10] Mar-

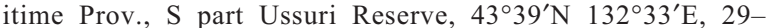
31.07.1998 (Yu.M. Marusik).

DIAGNOSIS. $P$. acuminus is very similar to $P$. maculatus, from which it can be distinguished by having a smaller embolus located prolaterally from conductor (embolus encircles conductor in P. maculatus). Females of both species are rather similar and can be distinguished by the straight margin of the anterior epigynal pocket in Far Eastern species, and rounded margin in European species. P. acuminus can be easily distinguished from Trachelas species occurring in Russia by having cusps on tibia-tarsi I and II in males, the lack of a patellar apophysis and the presence of an anterior pocket in the epigyne.

DESCRIPTION. Total length 3.7. Carapace 1.9 long and 1.5 wide. Carapace darker than abdomen. Abdomen without scutum. For a detailed description see Zhang et al. [2009]. Male legs I and II with cusps (Fig. 4). Palp (Figs 2-3) with unmodified femur and patella. Tibia with tapering retrolateral tibial apophysis direct- 


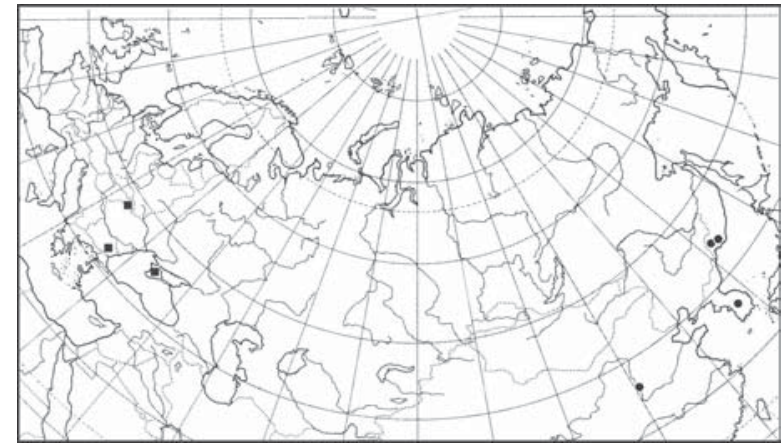

Fig. 5. Distribution of the genus Paratrachelas: square $-P$. maculatus; dot $-P$. acuminus.

Рис. 5. Распространение рода Paratrachelas: квадрат $-P$. maculatus; точка - P. acuminus.

ed slightly dorsally; length of apophysis is subequal to the heights of tibia. Tegulum with tapering conductor located on the retrolateral side of tegulum. Embolus shorter than conductor.

COMMENTS. Specimens from the Maritime Province are larger than the allotype male from China, which is 3.15 long, and has carapace 1.45 long and 1.23 wide.

DISTRIBUTION. This species is known from a single locality in China (Shanxi Province) [Zhang et al., 2009], Korea (number of localities unknown) and two localities within the Maritime Province in Russia (the present data).

\section{Family SPARASSIDAE Bertkau, 1872}

Although it is a large globally distributed family with over a 1000 species [Platnick, 2010] only one genus and species is known so far in Russia, Micrommata virescens (Clerck, 1757).

\section{Heteropoda Latreille, 1804}

COMMENTS. Heteropoda is large genus with 217 species (including subspecies) distributed in Southeast Asia, Australia and Pacific Islands [cf. Platnick, 2010]. Only two species known exclusively by females have been described and are known from South America and Africa [cf. Platnick, 2010]. Most probably they are misplaced.

\section{Heteropoda venatoria (Linnaeus, 1767)}

H. v.: Chikuni, 1989: 130, f. 1 ( (

H. v.: Song et al., 1999: 468, f. 269C, I $\left(\sigma^{7}+\right)$.

H. v.: Jäger, 2000: 53 , f. 1-7 ( $0^{7}+$ ).

H. v.: Namkung, 2003: 502, f. 40.3a-b (O'P).

H. v.: Jäger \& Kunz, 2005: 166, f. 48-53 (O'+

H. v.: Ono, 2009: 472, f. 16-19 (O' + ).

For an extensive list of synonyms see Platnick [2010].

MATERIAL EXAMINED. RUSSIA: 1 (ZMMU), Maritime

Province, S part, Sikhote-Alin Reserve, Dzhigitovka River mouth, seashore, July 2007 (collector unknown).
DIAGNOSIS. This species can be easily distinguished from other Far Eastern spiders because of its large size. From a single native sparassid Micrommata virescens, it can be distinguished by its larger size and dark coloration.

DESCRIPTION. Large species with female 25-30 $\mathrm{mm}$ long, and male 15-20 mm long. Dark coloured. Epigyne as in Figs. 6-10, three dimensional; anterior bands $(A b)$ raised over epigynal field $(E f)$; posterior lobe $(P l)$ larger than lateral lobe $(L l)$. For detail description see Jäger [2000].

COMMENTS. This species has Pantropical distribution [Platnick, 2010]. It seems that it was restricted to the Old World tropics, but later was spread by humans to other regions, including tropical parts of Florida, Texas and California. This species was reported several times from Germany and Switzerland from different cities, chiefly with Zoo [Jäger, 2000]. H. venatoria is known in adjacent Korea, China and Japan. With no doubt our record is based in introduced specimen although it was found in natural habitat. Besides Sikhote-Alin Reserve, one specimen was collected in Vladivostok. Photograph of $H$. venatoria female was sent to us by E. Kanyukova.

ACKNOWLEDGEMENTS. We thank Seppo Koponen who allowed us to use facilities in the Zoological Museum University of Turku and Yelena Kanyukova for sending us photograph of Heteropoda venatoria from Vladivostok. Draft of this paper was kindly reviewed by M.M. Kovblyuk and K.G. Mikhailov. The English of the final draft was corrected by R. Leech. This work was supported in part by the RFFI grants \# 09-04-01365 and 10-04-01424.

\section{References}

Bayer S., Jäger P. 2009. Heteropoda species from limestone caves in Laos (Araneae: Sparassidae: Heteropodinae) // Zootaxa. No. 2143. P.1-23.

Chikuni Y. 1989. Pictorial Encyclopedia of Spiders in Japan. Kaisei-sha Publ. Co. Tokyo. 310 pp.

Jäger P. 2000. Selten nachgewiesene Spinnenarten aus Deutschland (Arachnida: Araneae) // Arachnol. Mitt. H.19. S.49-57.

Jäger P., Kunz D. 2005. An illustrated key to genera of African huntsman spiders (Arachnida, Araneae, Sparassidae) // Senckenberg. biol. Bd.85. S.163-213.

Kovblyuk M.M., Nadolny A.A. 2009. The spider genus Trachelas L. Koch, 1872 in Crimea and Caucasus with the description of Paratrachelas gen.n. (Aranei: Corinnidae) // Arthropoda Selecta. Vol.18. No.1-2. P.35-46.

Marusik Yu.M. 2007. [Spiders (Arachnida: Aranei) of the Asian part of Russia: taxonomy, fauna, zoogeography]. Abstract of Doctoral Dissertation of Biological Sci. degree. St.-Petersburg: St.-Petersburg State Univ. 36 pp. [In Russian].

Marusik Yu.M., Guseinov E.F., Koponen S., Yoshida H. 2004. A new case of Caucasus-Far East disjunctive range in spiders (Araneae) // Acta Arachnologica. Vol.53. No.2. P.125129.

Mikhailov K.G. 1997. Catalogue of the spiders of the territories of the former Soviet Union (Arachnida, Aranei). Moscow: Zoological Museum of the Moscow State University. 416 pp.

Namkung J. 2003. The Spiders of Korea, 2nd. ed. Seoul: Kyo-Hak Publ. Co. 648 pp. 

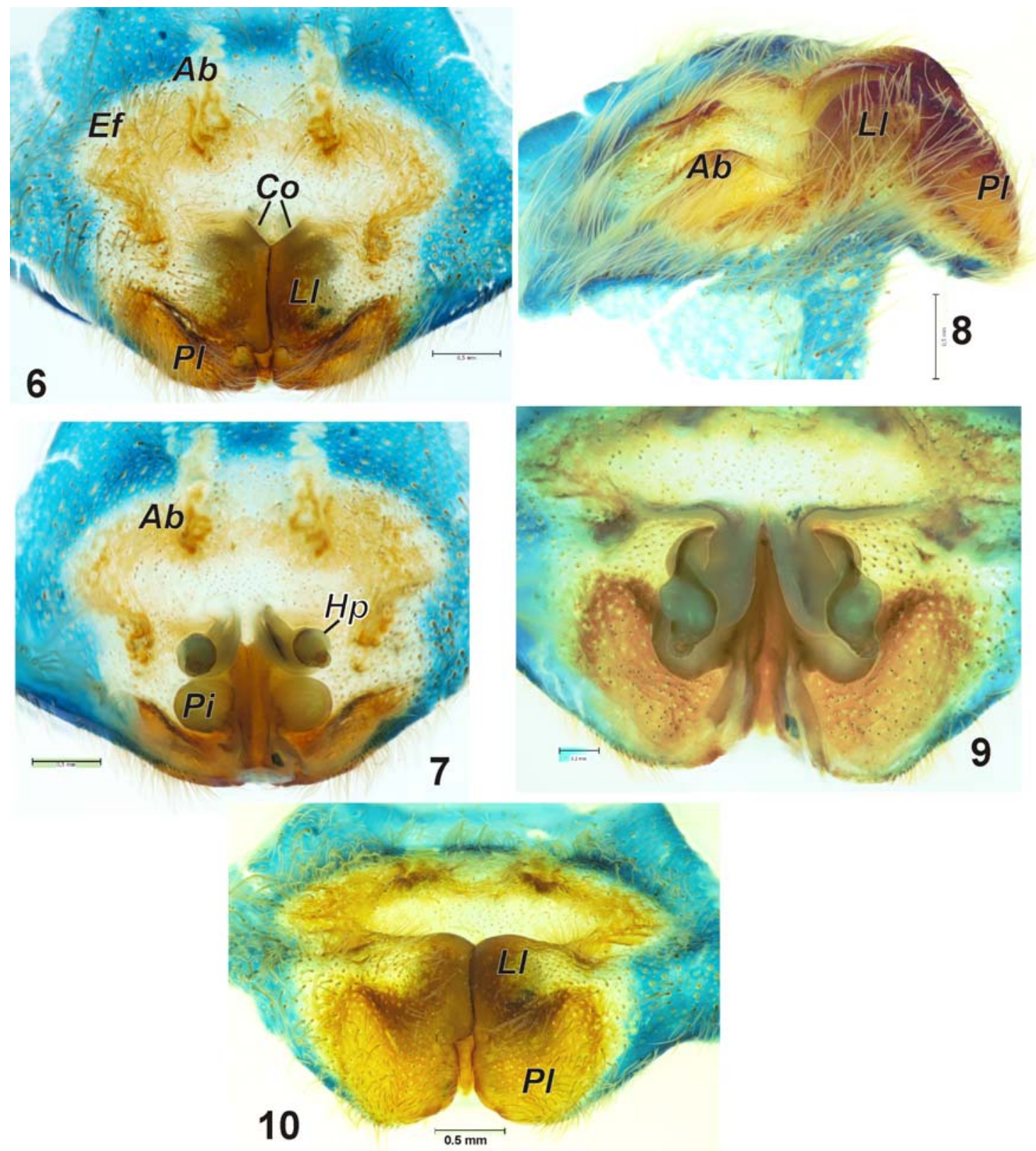

Figs 6-10. Epigyne of Heteropoda venatoria: 6 - ventral; 7 - dorsal; 8 - lateral, showing 3-dimensional shape; 9 - vulva anteriorly; 10 -caudal.

Abbreviations: $A b-$ anterior bands; $C o-$ copulatory opening; $E f$ - epigynal field; $\mathrm{Hp}$ - helical part of copulatory duct; $\mathrm{Ll}-$ lateral lobe; $P i$ - posterior part of internal duct system; $P l$ - posterior lobe.

Рис. 6-10. Эпигина Heteropoda venatoria: 6 - снизу; 7 - сверху; 8 - сбоку, покзана трёхмерная структура; 9 - вульва, спереди; 10 - сзади.

Сокращения: $A b-$ передние полоски; $C o-$ копулятивное отверстие; $E f$ - пластинка эпигины; $H p$ - закрученная часть эпигины; $L l$ - боковая лопасть; $P i$ - задняя часть семяпроводящих трубок; $P l$ - задняя лопасть.

Ono H. 2009. The Spiders of Japan with keys to the families and genera and illustrations of the species. Kanagawa: Tokai Univ. Press. xvi+739 pp.

Paik K.Y. 1991. Korean spiders of the genus Trachelas (Araneae: Clubionidae) // Korean Arachnol. Vol.6. P.197-206.

Platnick N.I. 2010. The world spider catalog, version 10.5. American Museum of Natural History, online at http://research.amnh. org/entomology/spiders/catalog/index.html
Song D.X., Zhu M.S., Chen J. 1999. The Spiders of China. Shijiazhuang: Hebei Sci. Technol. Publ. House. 640 pp.

Zhang F., Fu J.Y., Zhu M.S. 2009. A review of the genus Trachelas (Araneae: Corinnidae) from China // Zootaxa. No.2235. P.40-58.

Zhu M.S., An R.Y. 1988. Two new species of the genus Clubiona from China (Araneae: Clubionidae) // J. Hebei Normal Univ. (nat. Sci. Ed.) P.72-75. 